\title{
TERMINOLOGIJA V POKLICNEM VSAKDANU: STANJE IN POTREBE
}

Nataša LOGAR, Katja BENEVOL GABRIJELČIČ, Urban BREN, Sašo DOLENC, Katarina KRAPEŽ, Miro ROMIH, Mojca ŽAGAR KARER, Simon KREK, Vojko GORJANC, Mateja JEMEC TOMAZIN, Špela ARHAR HOLDT, Darja FIŠER

Logar, N., Benevol Gabrïelčič, K., Bren, U., Dolenc, S., Krapež, K., Romih, M., Žagar Karer, M., Krek, S., Gorjanc, V., Jemec Tomazin, M., Arhar Holdt, Š. in Fišer, D. (2016): Terminologija v poklicnem vsakdanu: stanje in potrebe. Slovenščina 2.o, 4 (1): 42-78.

DOI: http://dx.doi.org/10.4312/slo2.0.2016.1.42-78.

1 UVOD

V okviru konference Jezikoune tehnologije in digitalna humanistika je v petek, 30. 9. 2016, na Filozofski fakulteti v Ljubljani potekal panel na temo terminologije v poklicnem vsakdanu. $\mathrm{V}$ razpravi je sodelovalo šest govorcev oz. govork, in sicer Katja Benevol Gabrijelčič (Islovar), Urban Bren (Univerza v Mariboru, Fakulteta za kemijo in kemijsko tehnologijo), Sašo Dolenc (Kvarkadabra), Katarina Krapež (Univerza na Primorskem, Fakulteta za management), Miro Romih (Amebis, d. o. o., Kamnik), Mojca Žagar Karer (Inštitut za slovenski jezik Frana Ramovša, ZRC SAZU, Sekcija za terminološke slovarje). Razpravo je pripravila in povezovala Nataša Logar (Univerza v Ljubljani, Fakulteta za družbene vede).

Govorci in govorke so pred srečanjem v premislek in odziv prejeli naslednja štiri izhodišča:

1. V Sloveniji k terminologiji znanstvenoproučevalno pristopa več ustanov. Če bi našteli vse terminološke slovarje, glosarje in leksikone, nastale v zadnjih 50 letih, bi bil seznam kar dolg. ARRS je na tem področju financirala že več projektov. V zadnjem času je nastalo nekaj spletnih portalov, ki terminološke vire, pa tudi drugo s terminologijo povezano pomoč, nudijo brezplačno. Marsikatera strokovna revija ima redno rubriko, v kateri se avtorji posvečajo 
strokovnemu izrazju. Na forumih profesionalnih združenj so del debat pogosto prav terminološke zadrege in njihove rešitve. Strateški jezikovnopolitični dokumenti redno deklarirajo skrb za razvoj slovenske terminologije. Ob takem naštevanju se zdi, da je pomembnost področju pripoznana in delovanje na njem živahno. Zakaj torej to dvoje vseeno ni zadostno, zakaj so ugotovitve o stanju slovenske terminologijo vedno pospremljene z izrazi neusklajeno, nedostopno, neažurno, zlasti pa: premalo?

2. Prvi koraki $\mathrm{k}$ nastanku in ustalitvi terminov (ter $\mathrm{k}$ njihovi potencialni poznejši sistematizaciji $\mathrm{v}$ obliki terminoloških zbirk) so narejeni $\mathrm{v}$ štirih temeljnih sporočanjskih situacijah (Akcijski načrt za jezikovno opremljenost 2015: 11): (a) kjer znanje nastaja, tj. v znanstvenoraziskovalnem okolju; (b) kjer se znanje posreduje naprej, tj. $\mathrm{v}$ izobraževalnem okolju, še posebej $\mathrm{v}$ visokošolskem izobraževanju; (c) kjer se specializirana besedila pisno ali govorno prevajajo iz enega v drug jezik, tj. v prevajalskih okoljih, in (č) kjer se o znanju piše in govori v vseh ostalih situacijah, tj. v medijih, gospodarskih družbah, javnih ustanovah itd. Tvorci in/ali uporabniki terminologij v teh situacijah so različni ljudje z različnimi poklici ter različnimi sporočanjskimi nameni, vsi pa so zavezani odgovornosti uporabe pravilnega in natančnega ter za isto vsebino enotnega slovenskega poimenovanja. Kako poteka uresničevanje te odgovornosti v praksi? Kako se tvori in ustaljuje terminologija znotraj posameznih okolij (zlasti znanstvenoraziskovalno okolje in izobraževanje) ter kakšno je sodelovanje na ravni področni strokovnjaki : prevajalci (morda tudi novinarji in lektorji)? Kje nastopi kot svetovalec jezikoslovec terminolog? Kaj je v teh procesih najbolj zahtevno? Kaj je vredno pohvale? Kaj manjka, da bi bil pretok znanj še bolj učinkovit?

3. Slabost jezikov z manjšim številom govorcev je ta, da je pri njih finančnih in človeških virov manj, ne glede na to pa potrebujejo enak terminološki aparat kot vsi drugi jeziki (Krek 2014: 671). Sistematično predstavljena terminologija v obliki slovarja ali terminološke zbirke za stroko pogosto nima samo pojmovno-poimenovalne referenčnosti, temveč rada velja za njen - 
predvidoma odličen - izkaz, potrditev, spričevalo. Kdo so torej posamezniki in skupine, ki so pripravljeni sodelovati pri pripravi terminoloških slovarjev? Kaj jih motivira? V kakšnih razmerah delujejo in s čim si pomagajo? Pa tudi: kako je priprava slovarjev povezana $\mathrm{z}$ odpiranjem stroke navzven, $\mathrm{k}$ laični in mlajši populaciji?

4. $V$ zadnjem času so slovenske univerze začele vzpostavljati repozitorije svojih publikacij, ki vsebujejo raznorodna besedila, od doktorskih del, znanstvenih in strokovnih prispevkov do diplomskih nalog. Pomemben mejnik pri tem je leta 2013 vzpostavljeni Nacionalni portal odprte znanosti, ki vsebine iz teh repozitorijev agregira. Portal ponuja dostop do prek 123.00o slovenskih objav s širokega nabora strokovnih področij. Ta dela so izjemno dragocen, a zaenkrat še neizkoriščen vir terminoloških podatkov, zato je v letošnjem letu v okviru triletnega raziskovalnega projekta »Slovenska znanstvena besedila: viri in opis « iz besedil, vključeni v portal, nastal korpus KAS-proto (Erjavec idr. 2016). Korpus vsebuje več kot milijardo besed, zajema obdobje od leta 2000 do leta 2016, njegov največji del pa predstavljajo diplomska dela. Kot velika zbirka besedil bo torej KAS uporaben kot eden od virov za reševanje poimenovalnih zadreg, ki se sproti porajajo tistim, ki šele začenjajo s strokovnim in znanstvenim pisanjem, še bolj pomembno pa je to, da bodo v prihodnjih dveh letih iz korpusa po vedah in strokah izluščeni terminološki kandidati, ki bodo nato uvoženi v prosto dostopen spletni slovarski urejevalnik. To bo slovenskim znanstvenim in strokovnim skupnostim omogočalo upravljanje s terminologijo lastnih področij - torej nadaljnje urejanje $\mathrm{v}$ smislu brisanja neustreznih terminov, povezovanja sinonimov, dodajanja oz. popravljanja prevodnih ustreznic ter razlag ipd. Kakšen odziv strokovnih skupnosti je mogoče pričakovati? Kje so prednosti in kje pasti takega pristopa?

Izhodiščem so bila $\mathrm{v}$ pomoč pri pripravi na panel podana še naslednja vprašanja:

- Kakšne so vaše izkušnje s tvorbo/urejanjem/prevajanjem terminologije? 
- Kakšna je vaša ocena stanja urejenosti terminologije področja, s katerega prihajate? Kaj je dobro urejeno, kje so pomanjkljivosti?

- Kakšne rešitve vidite za težave?

- Kdo je po vašem mnenju odgovoren za reševanje težav? Kaj naj naredi jezikoslovje, kaj posamezne stroke, kaj država, kaj posamezne fakultete in inštituti, kaj stanovska društva? Na kolikšen doprinos posameznih deležnikov je mogoče realno računati?

- Kateri so dobri zgledi, ki jim je vredno slediti? Kje so trdna izhodišča, ki jih velja le še nadgrajevati?

Po uvodu je imel vsak od govorcev in govork nekaj minut časa za predstavitev svojega mnenja o naslovni temi in zgornjih izhodiščih, nato so sledila vprašanja moderatorke ter odgovori in replike. Zapis izjav je bil pripravljen po zvočnem posnetku, pri čemer so bile izjave za namene lažjega branja skladenjsko prilagojene značilnostim pisnega jezika. Govorci in govorke so na zapis posredovali še nekaj dodatnih pojasnil glede svojih prispevkov.

Zapis je pripravila Špela Arhar Holdt.

Mojca Žagar Karer: Na prvi pogled se zdi morda nepotrebno, ampak prvo vprašanje, ki si ga je smiselno zastaviti, kadar govorimo o terminologiji, je: Kaj sploh je terminologija? Če izhajamo iz opredelitve, da gre za poimenovanja pojmov, ki skupaj tvorijo pojmovni sistem stroke, lahko nadaljujemo $\mathrm{z}$ vprašanjem: Kdo termine ustvarja? Praviloma jih ustvarjajo tisti, ki pojme dobro poznajo in imajo znanje s konkretnega strokovnega področja, torej strokovnjaki. Za tiste, ki se ukvarjamo s terminologijo, pa je morda še pomembnejše vprašanje: Kdo so uporabniki terminologije? Uvrstimo jih lahko v več skupin. Prva skupina so gotovo strokovnjaki, ki termine uporabljajo pri komunikaciji z drugimi strokovnjaki, torej za sporočanje strokovnih vsebin. Druga, velika skupina uporabnikov so prevajalci, ki se s termini srečujejo pri svojem delu, ko celotna besedila, ki vsebujejo tako splošno leksiko kot tudi terminologijo, prenašajo v drug jezik. Ker pa je veliko terminov različnih strok 
prestopilo meje teh strok in se znašlo v splošnem jeziku, prej ali slej na posamezne termine naletimo tudi nestrokovnjaki.

Vsaka od teh skupin uporabnikov ima različne potrebe in pričakovanja in mislim, da je treba to upoštevati, preden se lotimo kakršnegakoli terminološkega projekta. V Sekciji za terminološke slovarje Inštituta za slovenski jezik izdajamo slovarje, ki so namenjeni zlasti strokovnjakom, zato se bom v tej kratki predstavitvi omejila na ta vidik. Strokovnjaki imajo pri nastanku naših slovarjev zelo pomembno vlogo: skrbijo za pojmovni del terminološkega dela in tudi za tujejezične ustreznike, ki morajo biti v stroki potrjeni termini, ne le prevodi v tuj jezik. Terminograf poskrbi za izdelavo specializiranega korpusa in pripravi osnutek geslovnika, ki dobi svojo končno obliko v sodelovanju s strokovnjaki. Pomaga tudi pri oblikovanju definicij in opozarja na morebitne pojmovne nedoslednosti. Po potrebi se včasih prelevi še $\mathrm{v}$ terminološkega svetovalca.

S sodelovanjem strokovnjakov in terminografov je v Sekciji nastalo kar lepo število terminoloških slovarjev. Trenutno jih je na spletišču Terminologišče objavljenih trinajst - zadnjega, urbanističnega, smo dodali ravno prejšnji teden. V pripravi je še druga izdaja veterinarskega slovarja. Sicer pa sodelavci Sekcije pripravljamo tudi nekaj slovarskih projektov z različnih področij: od večjih naj omenim pravo, živinorejo in agronomijo, od manjših pa recimo armiranobetonske konstrukcije in tiflopedagogiko. Izbor področij temelji na izkazanem interesu strokovnjakov. Naše načelo je, da nikoli ne zavrnemo skupine motiviranih strokovnjakov, ki pride do nas in si želi z nami sodelovati pri terminološkem slovarju svoje stroke, ne glede na to, ali gre za večjo ali manjšo, bolj ali manj znano stroko. Dejstvo je, da nekatere stroke (tudi v okviru različnih strokovnih združenj in terminoloških komisij na fakultetah) za svojo terminologijo skrbijo zelo dobro, skoraj zgledno, druge pa precej manj.

Terminološki slovarji so seveda samo eden od načinov prikaza terminoloških podatkov, ki pa je med uporabniki terminologije še vedno aktualen, kar kaže 
tudi priljubljenost novejših slovarskih portalov, ki vsebujejo množico slovarjev, recimo Frana ali Termanie. Ne glede na to, ali gre za terminološki slovar, terminološko bazo, terminološko podatkovno zbirko ali kaj drugega, je bistvo vsakega terminološkega dela pravzaprav opis, urejanje in ponavadi tudi usklajevanje terminologije. Pri tem se mi zdi veliko bolj kot neka simbolna funkcija terminološkega slovarja pomemben čisto pragmatičen cilj: preprečevanje nepotrebnih komunikacijskih šumov, torej preprečevanje situacij, ko se uporablja pet terminov za isti pojem, pri čemer nihče več ne ve natančno, ali gre pri vseh petih sploh še za isti pojem.

Ker je urejanje pojmovnega in poimenovalnega sistema posameznih strok kljub razvoju jezikovnih tehnologij, ki so seveda bistveno pohitrile in objektivizirale nekatere faze dela, še vedno precej zamudno, smo se v Sekciji pred dobrimi tremi leti odločili, da uporabnikom na Terminologišču ponudimo tudi terminološko svetovanje, s katerim poskušamo pomagati pri akutnih in aktualnih poimenovalnih potrebah. Število vprašanj iz leta v leto raste, tudi odzivi uporabnikov so zaenkrat zelo dobri. Primarno je terminološka svetovalnica namenjena strokovnjakom; od njih pričakujemo podroben opis problema, pri čemer je zelo pomembno, da je pojem jasno definiran. Šele potem lahko s pomočjo terminoloških načel poskusimo poiskati najustreznejši termin. Zanimivo je, da se tudi pri vprašanjih, ki pridejo v našo svetovalnico, kaže normativna narava terminologije: praktično vsi uporabniki si želijo odgovor na vprašanje, kateri termin naj uporabijo, torej kateri termin je po našem mnenju najbolj ustrezen.

Nataša Logar: Hvala, Mojca. Naj še dodam, da se boste med sabo lahko dopolnjevali za tem, ko vsak dobi besedo, zato zadržite misel. Na vrsti je Urban - področje biokemije, smo rekli prej. Vprašanje oz. iztočnica: Koliko in na kakšen način vas terminologija zadeva kot visokošolskega učitelja? Kakšno mesto ima v vašem poklicnem vsakdanu?

Urban Bren: V svojem poklicnem delovanju se s terminološkimi problemi 
srečujem tedensko, in sicer na dveh, treh področjih. Prva stvar je komunikacija predmeta študentom, ki zaenkrat - do najavljene spremembe zakonodaje ${ }^{1}$ vsekakor poteka v slovenskem jeziku. Druga stvar so diplome in magisteriji, ki morajo biti napisani v slovenščini. (Doktorati v manjši meri, ti so že dostikrat v angleškem jeziku.) Tu je treba termine, ki jih strokovnjaki v angleščini v resnici bolje poznamo in so nam bliže, spraviti v materni jezik. Kot tretje, v slovenskem jeziku publiciram poljudne in strokovne članke. Tudi takrat sem postavljen pred izziv: poznam angleški izraz in moram najti pravo slovensko ustreznico.

Mojca je prej lepo povedala, kako lahko nastopijo težave in komunikacijski šumi. Jaz bi se pa spustil v vprašanje, zakaj je terminologija pomembna in po svoje nujna tudi $\mathrm{v}$ slovenščini. Mislim, da se tega zavedamo številni univerzitetni profesorji, od tehnike, biotehnike do čistega naravoslovja. Jezik živi ali pade z možnostjo, da v svoje besedišče vpeljuje nove termine, izraze. Če bomo pogoreli na točki, da bodo novi izumi, dognanja brez slovenskih ustreznic, se bo slovenščina slej ko prej vrnila tja, od koder je prišla: v jezik podeželskega kmečkega prebivalstva. Tega se seveda zavedamo in za razvoj slovenskega terminološkega jezika skušamo skrbeti tudi ljudje, ki nismo jezikoslovci. Si pa tukaj velikokrat zelo osamljen: počutiš se, kot da si sam avtoriteta na področju in moraš, čeprav nimaš ustreznih jezikoslovnih podlag, priti s predlogom. Ni ti pa spet vseeno, kakšen je ta predlog. Obstajajo sicer določene reference. Na našem področju je $\mathrm{v}$ pripravi tehniški slovar, biokemijski slovar je že zelo kvalitetno postavljen. Na to se lahko opiraš. Ampak $\mathrm{v}$ resnici je prva stvar, ki jo narediš, da greš do svojih kolegov in vprašaš: »Ti, a si že kdaj na kaj podobnega naletel, kako si pa ti to prevedel?«

Projekt, ki ste ga tu zastavili, torej nabrati čim več terminov in jih posredovati v obdelavo strokovnjakom, je hvale vreden. Je pa po drugi strani dvorezen meč. Bom pri svojem raziskovalnem in pedagoškem delu, senatih in drugih

\footnotetext{
${ }^{1}$ Resorno ministrstvo je 26. 2. 2016 pripravilo predlog Zakona o spremembah in dopolnitvah Zakona o visokem šolstvu, ki je spodbudil javno razpravo o izbiri jezika v visokem šolstvu v RS (http://www.mizs.gov.si/si/zakonodaja_in_dokumenti/predlogi_predpisov/).
} 
komisijah, ki jih moram obiskovati, še razlagal strokovne pojme, ki mi jih pošljete? Težko, kljub temu da osebno sem motiviran. Tukaj umanjka: a) plačilo in b) kje se mi to vrednoti - ta moja skrb za jezik, da meni kot naravoslovcu ni vseeno? ARRS ${ }^{2}$ tega ne točkuje. To so sistemske zadeve, ki jih je treba nasloviti, če si želimo izboljšanja na področju terminologije.

Kot ste povedali, bi bila zelo dobra rešitev spletna aplikacija, ki bi združevala različne strokovnjake. Pridem do problema, kako prevesti nek termin, kako najti slovensko ustreznico. Ta problem bi bil odprt vsem strokovnjakom $\mathrm{s}$ področja. Kdo se je mogoče z njim že srečal in bi mi lahko napisal: »Ja, jaz sem uporabil to in to. « Krasno, že imamo precedens, kot bi se temu reklo. Zraven pa seveda tudi neko terminološko svetovanje jezikoslovca, ki bi povedal: »Se mi zdi ustrezno; se mi ne zdi ustrezno, « seveda ob naši razlagi, kaj si pod angleškim terminom predstavljamo. Ko je problem odkljukan, ko se strinjamo tako strokovni uporabniki kot terminolog, bi bilo pa škoda, da se rešitev ne bi spravila v neko bazo. To je povedano čisto z uporabniškega stališča - ko prvič naletiš na termin in si želiš slovenske ustreznice, pa si izgubljen, si vendarle naravoslovec, ne jezikoslovec. Toliko zaenkrat.

Nataša Logar: Tako, saj ravno uporabniški vidik nas je zanimal in nas bo tudi naprej. Katarina, pred kratkim ste doktorirali na temo pravnega varstva znanstvenih del. Gre za novo področje in predstavljam si, da ste na tej poti morali streti kar nekaj terminoloških orehov.

Katarina Krapež: Orehov, tako je. Jaz sem tudi predavateljica in moram priznati, da srečujem, kar je omenil Urban. Vse to srečujem. Poleg tega pa sem se kljub večletnemu predavateljskemu delu ob pisanju doktorata še vedno znašla v popolnoma enaki situaciji kot v študentskih letih. Kaj se je zgodilo? $\mathrm{Na}$ svojem področju že razviješ neko skrb ... Ja, skrb za jezik, mogoče celo ljubezen do jezika. Recimo, da to delamo že iz občutka odgovornosti, ker imamo pred sabo toliko in toliko študentov, ki bodo nekaj izvedeli od nas in morda nikoli

2 Javna agencija za raziskovalno dejavnost Republike Slovenije: http://www.arrs.gov.si/sl/. 
več. No, kaj se je zgodilo? Ko pravo (npr. avtorsko pravo, kar je moje področje), sreča drugo znanstveno področje - zlasti če gre za nekaj novega, recimo znanost o znanosti - se pojavijo vprašanja. Kaj je originalno v znanosti, odprti pristop in dostop v znanosti, kaj to pomeni? Takoj naletimo na zelo veliko terminov, ki jih v času pisanja doktorata še nisem našla prevedenih, ne glede na to, kako dolgo sem prevode iskala. Tu sem se znašla v situaciji, o kateri vsi tako radi govorimo: da je treba delati na več znanstvenih področjih, združevati področja - in sem zelo težko našla primerne sogovornike. $V$ tem smislu bi neke vrste terminološki slovar pomagal, a bi moral biti tako zelo specifičen, da ne vem, če bi se kaj takega res splačalo delati za vsako področje posebej oz. koliko je to sploh mogoče.

Kar pa se tiče svetovalnic, imamo pravniki pravne klinike. 3 To bi morda bilo nekaj, kar bi bistveno pomagalo doktorandom, študentom, da bi strli katerega od terminoloških orehov in ob tem mogoče postali malce samozavestnejši. Še nekaj moram poudariti. Kot nekdo, ki rad piše in mu ni čisto vseeno, kako zveni neka beseda, se ukvarjaš s tem. Predstavljam pa si, da se študentje oz. nekdo, ki piše doktorat in mora v določenem roku končati, s tem ne bo kaj dosti ukvarjal. Verjamem, da na ta način prihaja do ne preveč posrečenih prevodov, česar sem zelo veliko srečala. Pri pravniških kolegih me je mogoče malo presenetilo. Ponavadi smo zelo pikolovski, kar se tiče naše pravniške terminologije. Ko pa gledam, kaj delamo, ko vzamemo neko drugo področje ... No, bom raje tiho [smeh].

Tako bi strnila. Največ mi je pomagala naša lektorica, gospa je tik pred pokojem. $\mathrm{Z}$ njo sva imeli veliko debat ob tem, ko je lektorirala besedilo. To je bilo zelo koristno. Na terminološkem področju, kjer so termini strogo pravni, se sicer ponekod nisva mogli zediniti, drugod pa dosti bolj. Lepa izkušnja, ampak če si se res pripravljen spopasti s tem. Če ne, gre mimo in sploh ne opaziš, verjetno

\footnotetext{
3 Primeri npr. na Pravni fakulteti UL: http://www.pf.uni-lj.si/ob-studiju/pravna-klinika-zabegunce-in-tujce/ in v okviru mariborske Pedagoške fakultete:

http://www.pravozavse.si/pravna-klinika-v-mariboru/.
} 
pa je temu primerno tudi delo.

Nataša Logar: Hvala lepa zaenkrat. Miro, midva sva se spoznala pred kakimi petnajstimi leti in takrat ste me razsvetlili s spoznanjem, da je v slovenskem prostoru še kup slovarjev, ki jih imajo ljudje na svojih računalnikih, in da se na vas, na Amebis, obračajo z željo, da bi te slovarje dali v javnost. Je še vedno tako?

Miro Romih: Še vedno, ampak vedno manj. Časi so se spremenili. Pred petindvajsetimi leti, ko smo se začeli ukvarjati s tem, so bili slovarji tiskani. (Ne govorim le za terminološke, ampak splošno za slovarje. Takrat smo vstopili kot računalniško podjetje za tehnično rešitev problema, kar pomeni enako, če rešuješ problem dvojezičnega ali terminološkega slovarja.) Problem je bil, ker so bili slovarji pač debeli cegli, na drugi strani pa diskete. Kako tak slovar, npr. Debenjakov nemško-slovenski slovar, spraviti na računalnik uporabnika? Disketa je takrat obsegala recimo 1,2 MB ali 1,4 MB prostora. Na začetku smo torej reševali v glavnem ta problem, recimo SSKJ je izšel na dvanajstih disketah, Šlenc na dveh disketah. No, čas je tekel, konec devetdesetih smo vsak slovar že spravili na en sam CD-ROM, pa je veliko prostora še ostalo.

Sam problem uporabnikov je $\mathrm{v}$ osnovi ostajal, ampak se je $\mathrm{s}$ časom začel spreminjati. Sploh zdaj, ko smo prišli v dobo spletnih slovarjev. CD-jev in disket ni, s spletno rešitvijo dostopamo do vseh platform: Appla, Linuxa, Microsofta itd., da lahko uporabniki delajo na različnih napravah. Spremenila se je tehnologija, uveljavila so se nova orodja in s tem so se spremenile tudi navade uporabnikov. Pojavile so se nove rešitve, kot so prevajalni sistemi, ki jih navadni smrtniki, če se tako izrazim, za razliko od prevajalcev uporabljajo kot ekvivalent slovarjem. Nekateri celo raje kot slovarje, ker je bolj ugodno: vneseš tekst, dobiš prevod, kakršenkoli že pač je. Skratka, navade so se spremenile.

Zdaj je tako: na eni strani imamo uporabnike, na drugi avtorje, na tretji založnike, če štejem še nas (firma, ki izvede določeno rešitev), smo štirje. Kar se tiče založnikov, vsi vemo, kakšna je situacija - razen mogoče na ZRC SAZU, ki 
po funkciji še nekaj dela. Praktično vse založbe so svoje slovarske oddelke zaprle. To ni več profitabilna zadeva, s tem se noče nihče več ukvarjati. Na nek način smo med redkimi, če ne edini, ki na tem segmentu vztrajamo in na lastne stroške delamo uslugo študentom, ki pišejo diplomske naloge in pripravljajo lastne terminološke slovarje, vzdržujemo strežnik Termania ... Včasih uspemo pridobiti kakšna sredstva, da prenesemo določene slovarje nanj. Trenutno imamo okrog petdeset napol odprtih slovarjev in okoli tri milijone geselskih člankov, ki so brezplačni.

Avtorji imajo pa problem, ker se je poslovni model povsem spremenil. Včasih je avtor napisal slovar, bil za to plačan, založba mu je nekaj pobrala, vsi so lepo živeli - in uporabniki so seveda morali za slovarje plačati. Danes imamo internet in vsi pričakujejo, da bodo slovarji brezplačni, sicer bodo uporabljali druge, ki so brezplačni, čeprav slabši. Avtorji nimajo več vira plačila. Na nas se npr. obračajo profesorji, ki imajo napisane slovarje. Nimajo dovolj znanja, da bi te slovarje sami objavili in približali uporabnikom, imajo pa izbiro: ali jim obleži v predalu, pa nihče ne ve, da je slovar kadarkoli obstajal, s čimer gre vse njihovo delo v nič - ali pa ga uspejo spraviti na medij, kjer ga lahko še kdo uporablja, in ostane za njimi vsaj ime, če tako rečem.

Problemi so torej, ker se je sistem spremenil. Smo v situaciji, ko potreba po slovarjih je, taka ali drugačna, ni pa motiva za avtorje dobrih slovarjev, ker ni več plačnika zanje. (Dvomim sicer, da bi za rešitev tega problema zadostovala sistemska podpora države, ki bi financirala pisce slovarjev. Do neke mere mogoče, ampak dvomim.) Tu vidim glavni problem za vse vrste slovarjev: ne samo terminološke, ampak tudi ostale. O tehničnih zadevah pa še kasneje.

Nataša Logar: Že prej in zdaj še z Mirove strani smo slišali nekaj o dobri volji, notranji motivaciji in altruizmu, pa bomo v tej smeri kar nadaljevali. Katja, sodelovanje pri Islovarju je vaša prostočasna dejavnost. Nekateri gredo na golf, vi greste na sestanek terminološke skupine. Kaj to sodelovanje zahteva, kaj vas motivira? 
Katja Benevol Gabrijelčič: Najprej bi povedala, kako sem sploh prišla do Islovarja. Kot rečeno, sem prevajalka, primarno prevajalka tehničnih strok. Rada bi izkoristila priložnost in povedala, da danes praznujemo svetovni dan prevajalcev, ker goduje sv. Hieronim.

Miro Romih: Bomo potem kakšnega spili [smeh]?

Nataša Logar: Ob večerji [smeh].

Katja Benevol Gabrijelčič: No, s prevajanjem sem se začela intenzivneje ukvarjati daljnega leta 1995, ko še ni bilo interneta, in sem bila ena redkih slavistk, ki je zelo hitro zajadrala v računalniške vode. Takrat je bila to res redkost, veste - jaz sem čakala dva meseca, da sem dobila dostop do Arnesa 4 [smeh]. Ker sem bila že od študentskih let dalje veliko med računalniki, so me hitro našli tudi tehnični prevodi s tega področja in posledično se mi je ustvarjal nekakšen geslovnik. Od leta 1998 dalje sem nekaj let lektorirala Monitor, PC\&Medije, Escape, prevajala bele knjige za Microsoft, nekaj let sem bila tudi jezikovna svetovalka za Lotus. Tako sem leta 2001 naletela na Islovar, pri čemer se mi zdi najbolj zanimivo, da še dandanes nekateri z računalniškega področja niso naleteli na Islovar, kar verjetno dosti pove o povezovanju in tako dalje. Urednikom sem ponudila svoj geslovnik, ki je obsegal približno petsto besed, kar se mi sicer ni zdelo veliko (bilo je seveda plod dolgoletnega dela), ampak sem se kasneje, v zadnjih dvanajstih, trinajstih letih naučila, da to sploh ni tako malo. Takrat je Islovar obsegal približno 2500 besed, danes jih ima 700o, od tega približno 2600 urejenih. (Kaj pomeni, da so urejene, bom povedala malo pozneje.) Nekaj je bilo uvajalnega obdobja, občasnega sodelovanja, in potem sem začela hoditi na slovaropisno skupino, ki je v bistvu zadnja stopnja oziroma skoraj zadnja stopnja urejanja neke iztočnice.

Delo pri Islovarju poteka tako: Islovar je odprt, javno dostopen, kdorkoli se lahko prijavi in vanj vnaša iztočnice oz. gesla. Zaželeno je, da imajo vsaj

\footnotetext{
4 Akademska in raziskovalna mreža Slovenije je javni zavod, ki zagotavlja omrežne storitve organizacijam s področja raziskovanja, izobraževanja in culture (http://www.arnes.si/).
} 
nekakšno razlago, ker bi smeli uporabniki domnevati, da če že imajo prevod za ta izraz, je to zato, ker so ga dodali in uredili strokovnjaki na nekem področju, mi pa nismo strokovnjaki za vsa področja. Računalništvo je namreč taka čudna žival, ki ga obvladajo vsi in ki zajema vsa področja našega življenja. Včasih ni bilo tako, danes je tako. Danes se ukvarjamo s fotografijo v računalništvu, s tiskarstvom $\mathrm{v}$ računalništvu, z ekonomijo $\mathrm{v}$ računalništvu, s poslovnimi procesi v računalništvu; in če imaš strokovnjaka, ki ga lahko karkoli vprašaš, imaš občutek, da si zadel na loteriji.

Ko je izraz zaveden (z razlago ali brez), prej ali slej pride v določeno zbirko, ki jo ustvari urednik ali uredniška skupina. Ta zbirka se potem ureja. Ni pomembno, s kako veliko zbirko začneš. V slovaropisni skupini je legendarna iztočnica znak, za katero se je v prvem momentu ustvarila zbirka ... Mislim, da od štirinajst do dvajset besed ali nekaj takega. In v nekaj mesecih je ta zbirka narasla na sto petdeset izrazov. To je bilo nekaj mesecev vsakotedenskega dela in maratonskih sestankov: ko enkrat imaš določen izraz in ga razložiš, iz razlage pobereš nove izraze, ki jih še nimaš v slovarju in jih moraš vnesti. Potem to eksponentno rase naprej. Ta je bila res ... Po mojem je ne bomo pozabili, more so nas tlačile, ko smo delali to zbirko. Je pa res - dve uri šest ljudi razpravlja o izrazu za izrazom, za izrazom, za izrazom. Če imaš srečo, jih narediš v dveh urah deset, če nimaš sreče, ostaneš pri dveh. In mogoče si jih nekaj preusmeril z »glej«, da si vsaj malo normativen in si nekaj počistil.

Kot sem rekla: enkrat na teden, dve uri, popoldne, prostovoljno, načeloma. Zakaj načeloma? To, da je delo prostovoljno, pomeni, da ima vse drugo prednost: službene obveznosti - jaz imam recimo roke za oddajo prevodov, profesorji imajo študentarijo, izpite - morebitna potovanja, družinske obveznosti. In seveda zdravje. Zakaj to posebej omenjam? Jaz sem sicer že siva, ampak v slovaropisni sem daleč najmlajši član skupine. Daleč najmlajši [smeh]. Vsega, kar vemo o urejanju slovarja, nas je naučila gospa Zvonka Leder Mancini. Tisti, ki ste slišali zanjo, veste, da je urejala SSKJ, in to tistega prvega, ceglastega [smeh]. Gospa Puc je že dolgo upokojena, vendar je še vedno gonilna 
sila, ki nas enkrat tedensko zbobna skupaj, če ji le uspe. Potem je tu še gospod Ivan Kanič, ki je sodeloval pri bibliotekarskem slovarju in mu menda tudi ne manjka veliko do upokojitve. Skratka, iščemo nove žrtve, ki bi prostovoljno in brezplačno hodile k nam na delo.

Prej sem na predavanjih 5 slišala, da se sklepa neka pogodba in da se bo $\gg \mathrm{z}$ borimi osem tisočaki« nekaj naredilo. Mi na zadnjih razpisih ministrstva za podobne iniciative nismo dobili nič. Nekaj let nazaj smo dobivali po petsto evrov na leto za vseh nas šest. Nekaj malega prispeva Slovensko društvo Informatika, ker je Islovar produkt jezikovne sekcije. Tako pač gre in tu se neha: ko ljudem razložiš, da lahko samo vlagajo svoje delo. Zadnje čase se interes porazgubi, še preden spodbudiš kakšen plamenček interesa in družbene odgovornosti do jezika, stroke in vsega ostalega. Tu nekje smo. Najbolj sem se ustavila pri tistem stavku, kaj nas motivira. Domnevam, da nas v štartu dejansko motivira ljubezen do jezika - mene kot prevajalko sploh, ampak tudi računalniške strokovnjake, ki so tukaj zraven - in taista odgovornost $\mathrm{s}$ profesorskega stališča. Konec koncev se z nečim ukvarjaš, da boš lahko študentom na ustrezen način predstavil svojo stroko. Ampak občasno ti zmanjka zanosa.

Nataša Logar: Ja, pri čemer naj dodam, da Islovar vedno omenjamo kot odličen slovar, po mednarodnih standardih usklajen z najboljšimi slovarji. Mislim, da bi mi Sašo prikimal. Ampak naj še dodam: ko človek piše o znanosti, o posameznih ugotovitvah in področjih znanosti, ter predava poljudno nekomu, ki ni strokovnjak na tistem ozkem področju - pripravlja oddaje, kakršna je denimo Frekvenca $X$, mora verjetno velikokrat reševati terminološke zadrege takoj. Tudi vprašanja tipa »kako se nečemu reče v slovenščini «, ki so jih omenjali kolegi, sodijo sem. Kako ravnati takrat? Kaj storiti, ko je treba najti hitro terminološko rešitev? Kaj pomaga ali vsaj - kaj bi pomagalo? Kaj mora

$5 \mathrm{Na}$ konferenci Jezikovne tehnologije in digitalna humanistika 2016 (http://www.sdjt.si/wp/dogodki/konference/jtdh-2016/). 
biti takoj pri roki?

Sašo Dolenc: Prva stvar je, da vtipkaš v Google. Potem greš gledat po zadetkih in se že kaj porodi.

Nataša Logar: To je realnost.

Sašo Dolenc: To je realnost.

Nataša Logar: Izvolite, pripravili ste si tudi uvodno misel.

Sašo Dolenc: Pred nekaj tedni sem na Facebooku opazil reklamo za novi Sinonimni slovar slovenskega jezika. Verjetno ste že vsi slišali za to. In sem bil zelo navdušen, ker se mi je zdelo, da gre izvrsten priročnik, ki mi bo v veliko pomoč pri pisanju. Ampak ko sem malo podrobneje preučil predstavitev novega izdelka, sem ugotovil, da slovar naslavlja uporabnike, kakršnih danes skorajda ni več.

Kaj mislim s tem? Slovar bo izšel v papirnati obliki na okoli 1300 straneh v formatu velikosti A4 v trdi vezavi. Za večino današnjih piscev, ki ima ves čas pri roki spletna orodja in Google, je velika, težka knjiga v omari za vse praktične potrebe žal preveč oddaljena in okorna, da bi jo lahko aktivno uporabljali. Ko sem si pred približno desetimi leti kupil podobno velik slovar Veliki slovar tujk, sem hitro ugotovil, da naložba v debelo, težko knjigo ni bila preveč pametna. $\mathrm{V}$ vseh teh letih sem slovar tujk vzel s police in ga odprl le kakih petkrat. Izkazalo se je namreč, da je bistveno lažje in hitreje odgovor na terminološko dilemo poiskati nekje na spletu kot pa v fizični knjigi, ki je daleč v omari. Navade se s prihodom novih tehnologij seveda spreminjajo. Tako kot danes nihče več ne odpira papirnatih enciklopedij, ampak uporablja za začetno seznanjanje z novo tematiko zgolj še Wikipedijo in podobne vire na internetu, tudi slovarjev v praksi ne uporabljamo več v papirnati obliki, kot smo jih nekoč. In tega ne govorim le iz svojih izkušenj, ampak sem povprašal tudi nekaj kolegov in kolegic in vsi so mi povedali, da počnejo isto.

Posebej zabaven se mi je zato zdel odgovor na vprašanje »Ali je smiselno 
dandanes izdajati slovar v tiskani obliki? «, ki je naveden v rubriki »Pogosta vprašanja« na reklamnem letaku za novi sinonimni slovar. Ta odgovor bom prebral kar v celoti.

Spletni pogled nikakor ne more nadomestiti izkušnje, ki nam jo omogoča tisto, čemur rečemo »listanje po knjigi«. Pri spletnem slovarju si težko predstavljamo, kako je slovarski sestavek umeščen med druge sestavke, kaj stoji pred njim, kaj za njim in koliko obsežen je slovar. Poleg tega Sinonimni slovar slovenskega jezika ni samo slovarski priročnik; je tudi knjiga, namenjena vsem, ki uživajo v bogastvu poimenovalnih možnosti slovenskega jezika. Zato se lahko pričakuje, da ga bodo bralci najraje prelistavali v tiskani obliki (Brošura Sinonimni slovar slovenskega jezika 2016: 5).

Ko sem prebral to pojasnilo založbe, sem najprej pomislil, da gre za kako komercialno šalo [smeh]. Ampak so me kolegi prepričali, da dejansko še obstajajo ljudje, ki se jim zdi listanje debelih papirnatih knjig vrednota sama po sebi, ne glede na to, kakšna je uporabna vrednost tega in za kakšen tip knjige gre. Vseeno sem prepričan, da se velika večina ljudi danes že dokaj dobro zaveda, da se morajo napredku tehnologije pisanja in branja prilagoditi tudi jezikovni priročniki. Sploh, ker vsi pišemo bolj ali manj zgolj še s pomočjo računalnikov, tablic in telefonov. Prav na področju strokovne terminologije, o čemer se danes pogovarjamo na tej okrogli mizi, imamo pri nas nekaj dobrih primerov, kako lahko s pomočjo novih orodij in tehnologij uspešno skrbimo za razvoj strokovnega jezika.

Izpostavil bi dva primera, nekaj pa smo jih že tukaj slišali. Večkrat obiščem spletno stran terminološke komisije Slovenskega biokemijskega društva, npr. če iščem slovenski prevod za kak termin s področja znanosti o življenju. Gre za vsebinsko zelo bogato spletno stran, za katero skrbi skupina raziskovalcev in jo redno dopolnjuje. Ker pa je informacij na strani že zelo veliko, se je na njej težko znajti in bi jo bilo treba tehnično nadgraditi. Druga stvar pa je zelo pregleden Islovar, ki ga tudi uporabljam. Tam je pa tehnološko vse popolno: vtipkaš, dobiš zadetke in vse super deluje. 
Po internetu je še veliko podobnih terminoloških slovarjev, ki jih pripravljajo razna strokovna društva. Zato bi bilo dobro vse to združiti na enem mestu, opremiti s tehnologijo, o kateri je bilo prej govora, in ljudi obvestiti, da lahko na enem mestu najdejo vse skupaj. Ko sem se pripravljal za tole diskusijo, sem ugotovil, da pri Amebisu že imate Termanio (če sem prav izgovoril), ki je mogoče zametek nečesa podobnega. Mogoče obstaja še kaj drugega. Ampak je še zelo vsebinsko skromna, preizkusil sem nekaj gesel, ki sem jih zadnje čase iskal, pa ni bilo zadetkov.

No, pri jezikovnih orodjih je uporabniška izkušnja zelo pomembna, zato ni razloga, da za jezik ne bi skrbeli tudi z vsemi modernimi digitalnimi orodji, ki so nam na voljo. Domnevam, da večino slovarskih in podobnih jezikovnih projektov financira država, zato bi bili lahko prosto dostopni in tako v bolj množični uporabi. Ne vem, se mogoče motim? Zadnje mesece se je ponovno razplamtela debata o ogroženosti slovenščine v strokovnih krogih, zato bi v razmislek za konec postavil hipotezo, da slovenščino dolgoročno mogoče še najbolj ogroža prepočasno sledenje novim jezikovnim tehnologijam, ki jih drugi jeziki bistveno hitreje razvijajo in vnašajo v vsakdanjo množično uporabo.

\section{[Aplavz publike.]}

Nataša Logar: Odziv pove vse in tudi ostali govorci ste že nakazali rešitve, tako da bi šli sedaj vsi skupaj na izhodišče, v iskanje rešitev v tem kratkem času. Ker smo na koncu rekli, da je treba iti na splet, biti brezplačen, »na klik«, dostopen in podobno, gremo najprej na tehnični del. Miro, kje vidite rešitve sami, s svojo ekipo?

Miro Romih: Že pri zasnovi Termanie, ko se je era CD-jev končevala, smo izhajali iz dejstva, da je prihodnost medijev splet, kar pomeni, da moramo tudi slovarje prenesti v splet. Gledali smo, kakšne so potrebe glavnih dejavnikov: na eni strani uporabnikov ter na drugi strani avtorjev. Založb ni več, stvar je brezplačna, zagotoviti moramo vsebino in jo $\mathrm{v}$ primerni obliki tudi podati uporabnikom. Če izhajamo iz potreb ali problemov uporabnikov, je prvi 
problem lahko, da ni slovarja. Lahko slovar obstaja, a morda v obliki knjige, ki je že razprodana; ali je skrit $\mathrm{v}$ kakšni diplomski nalogi in pravzaprav ni dostopen. $\mathrm{V}$ tem primeru informacija sicer obstaja, ampak je nismo pripeljali do uporabnika. Tretji problem je včasih tudi, da informacije so, ampak za isti izraz v treh slovarjih na različnih spletnih mestih, vsak slovar v povsem svoji tehnični obliki, po možnosti je tudi vsaka od definicij malo drugačna. Kar pomeni, da imamo spet problem, komu verjeti, kateri izraz uporabiti. Problemov je torej več. Če slovar obstaja, je lahko problem tudi cena - če ga je treba kupiti, pa npr. nek študent ali kdorkoli nima dovolj denarja. Saj vemo, da slovarji večinoma niso bili ravno poceni.

Kako lahko te probleme rešimo? Po tehnični plati Termania problem že rešuje. Glavna ideja je bila, da slovarje pripeljemo na eno mesto. Treba je bilo narediti iskalnik, v katerega vpišeš izraz in ki preišče vse slovarje v sistemu ter ti da zadetke. Pomemben je že vrstni red zadetkov, prva informacija, ki jo dobiš, in Termania tako tudi deluje. Ko iščeš izraz miza, dobiš najprej vsa gesla ali geselske članke, kjer je beseda miza iztočnica. V nadaljevanju sledijo gesla, kjer je miza del iztočnice, npr. pisalna miza in termini. Zatem vsa gesla, kjer je miza prevod iztočnice, še zatem (v četrtem delu) pa gesla, kjer se miza pojavlja kje drugje v geslu. ${ }^{6}$

$\mathrm{Na}$ Termanii smo nameravali zbrati vse vrste slovarjev, tako enojezične kot večjezične, tako terminološke kot splošne, tako simetrične kot nesimetrične, če temu tako rečemo (tj. da so terminološki slovarji simetrični, pojmovni, vsako geslo predstavlja en pojem; večina slovarjev pa je nesimetričnih, kar pomeni, da geslo lahko predstavlja več pomenov). Kako narediti enovit sistem, ki podpira iskanje in prikaz $\mathrm{v}$ tako raznoliki množici, $\mathrm{v}$ kateri ima vsak v tej vrsti slovarjev svojo strukturo s svojimi elementi? Odločili smo se izpostaviti iztočnico, ker jo imajo vsi geselski članki v vseh slovarjih. Za iztočnico sledi

${ }^{6}$ Geslo miza na portalu Termania:

http://www.termania.net/iskanje?query=miza\&SearchIn=All. 
definicija, prevod in vse ostalo. To je nekako skupni imenovalec sistema.

Kot sem prej povedal, tudi pri zadetkih potem upoštevamo: a) jezik vmesnika: če iščemo po angleškem vmesniku in če je slovar večjezični, so rezultati za Angleža nekoliko drugače razporejeni kot za Slovenca; b) abecedni vrstni red; c) predvsem pa prioriteto slovarja: na vrh damo bolj relevantne slovarje $\mathrm{z}$ boljšimi informacijami, po katerih ljudje večkrat iščejo, za njimi pa manj pomembne slovarje. Imamo nekaj sto slovarjev, po katerih se mora uporabnik seveda čim hitreje znajti in pripeljati mu moramo pravo informacijo. Seveda obstajajo še filtri, da lahko uporabnik filtrira po enem, več ali vseh slovarjih po izvornem ali ciljnem jeziku. To je v enostavnem iskanju. V naprednem iskanju pa lahko iščemo še po dodatnih področjih in podobno. Iskanje je torej prva stvar, s tem da damo na prvo mesto samo informacijo: iztočnica plus definicija ali prevod. Se pravi, kar ljudje najpogosteje potrebujejo. Ko pa greš v globino, izbereš geslo in dobiš celoten geselski članek. Tam je vsa struktura v obliki, v kakršni je slovar narejen. To je bilo zdaj povedano za uporabnike.

Nataša Logar: Za uporabnike. Se pravi znamo ...?

Miro Romih: Tako, tehnološko znamo. Za uporabnike je obstajala še ena ideja, ki je nismo imeli možnosti realizirati. In sicer, da bi se zadetki prikazali kot nekakšen zbir informacij iz različnih slovarjev. Ko npr. iščeš besedo miza, dobiš v enem zadetku takoj izpis vseh definicij iz slovarjev, v katerih pač definicija obstaja - na enem mestu, z navedbo vira, seveda. V drugem zadetku so vsi prevodi po jezikih in naprej še ostale informacije. Termania ima nekaj nerealiziranih idej, predvsem zaradi financiranja, ker te ideje zahtevajo več dela. To je namreč projekt, s katerim se ukvarjamo poleg drugega dela.

Sašo Dolenc: Ampak je pa zaprt sistem, ne? Slovarji, ki jih daste ...?

Miro Romih: Ne, ne, bom povedal. Drugi del, ki je ključnega pomena, je podpora avtorjev, ker tudi uporabniku nimamo česa dati, če ni avtorja, če torej nimamo slovarja. To pomeni, da je najbolje, če je na Termanii oziroma $v$ sistemu, kot smo si ga zamislili, na voljo tudi vse potrebno orodje za avtorje, ki 
slovarje pišejo. Da imajo vse tam. Te potrebe smo srečevali, ko so nas ljudje klicali. Avtorji so imeli drugačne probleme kot uporabniki. Najprej tehnično neznanje (kot sem rekel, ima vrsta profesorjev strokovno znanje, ne pa tehničnega). Slovar imajo izdelan, pripravljeni so ga dati, ne bi pa nam plačali treh ur dela, da slovar spravimo na Termanio. Tri ure se ne sliši veliko, ampak če je slovarjev petsto, je s tem veliko dela - za nič. Eno je torej to: strošek, tehnično znanje, včasih tudi strokovno znanje. Veliko avtorjev se je, ko so pisali nov slovar ali predelovali starega, srečevalo s pomanjkanjem osnovnega leksikografskega znanja. Pa so se tudi obračali na nas, ker so mislili, da smo mi tisti, ki pišemo slovarje, čeprav nismo.

Nataša Logar: Potem morajo pa k Mojci.

Miro Romih: Ja, saj sem jih napotil na Simona [Kreka], dokler je bil še na DZS oz. njihovem slovarskem uredništvu, sedaj jih na ZRC. Mi imamo neka osnovna znanja, ampak nismo strokovnjaki za to področje.

Predvsem pa imajo avtorji problem z orodji, s katerimi izdelujejo slovarje. $\mathrm{Ne}$ vedo, kaj bi uporabili. Večina jih slovarje napiše v Wordu ali Excelu in potem moramo to pretvarjati, da dobimo XML, ki ga lahko vključimo v naš portal. Večina avtorjev je nestrokovnjakov, niso leksikografi. To se pravi, mora biti orodje enostavno. Glavna zahteva pa je, da editor oz. spletni urejevalnik omogoča urejanje vseh možnih slovarjev - kot sem že prej rekel: taka struktura, druga struktura, tretja struktura - in to naš spletni urejevalnik tudi omogoča. Osnovne funkcije zdaj imamo, manjkajo pa tri, štiri funkcionalnosti, ki smo si jih že tudi že zamislili in so zelo pomembne, da bi se stvar razvila. Ena od teh je uredniški sistem, kot ga imate pri Islovarju (in o katerem smo se pogovarjali že pred leti, pa prenos slovarja na Termanio ni uspel): dodeljevanje uredniške vloge posameznim avtorjem. Vsako geslo dobi značko, ki bi se videla tudi pri objavi gesla, npr. kako je nekdo prispeval, ali je geslo še neurejeno, v neki fazi urejanja ali potrjeno. $\mathrm{S}$ tem sta povezana tudi prikaz zgodovine ter primerjava, kdo je kaj spremenil. 
Drugo, kar manjka, je forum, na katerem bi lahko avtorji komunicirali med sabo. Poleg tega pa možnost, da lahko uporabniki k vsakem geslu dopišejo svoje pripombe, npr. »Tukaj imate napako, » To je narobe zapisano « in tako naprej. To smo že imeli v eni od verzij, pa smo umaknili. Ko je avtor vstopil v urejevalnik, je imel na desni strani vse pripombe uporabnikov in ob kliku je padel v geslo in lahko to upošteval. Se pravi, kontakt uporabnikov. Verjetno sem še kakšno stvar pozabil, ampak to so načeloma stvari, ki so bile zamišljene, niso pa še do konca izpeljane.

Aha, to sem pozabil: odprtost oziroma zaprtost slovarjev. Vsi slovarji so zapisani v XML-u. Nova Termania ima tudi čarovnika, kjer si lahko vsak naredi svoj slovar. (Recimo, kot sem videl, so si ga astronomi že naredili (Zwitter), je že objavljen.7 Prvi, ki so ga naredili s čarovnikom, in ima nekaj sto, morda tisoč gesel. To je bilo dodano.) Na voljo je nabor sedmih relativno enostavnih struktur, ki so sedaj ponujene vnaprej, a bi lahko dodali še nove. Standard na področju terminoloških slovarjev predstavlja TBX, ki je pomemben zaradi uvoza neposredno v prevajalnike. Na Termanii lahko nosilec avtorskih pravic slovar izvozi ali tja uvozi v XML-obliki. Če mu torej urejevalnik premalo omogoča, si lahko slovar izvozi, uvozi v nek profesionalni XML-editor, naredi, potem uvozi nazaj - samo zato, da je uporabnikom na voljo v vsakem trenutku. Toliko, da ne bom predolg.

Nataša Logar: Saj bomo kar iz tega izhajali. Se pravi: imamo portal. Tudi pri projektu TERMIS smo uporabljali Termanio in bili zelo zadovoljni. Kako naprej? Če bomo na ta portal iz našega velikega korpusa uvozili terminološke kandidate z različnih področij, ali bo odziv? To je moje naslednje vprašanje. Saj vsi ugibamo, ampak ... Se bodo oblikovale znanstveno-strokovne, za terminologijo zainteresirane skupnosti, ki bi ta portal uporabljale? Bo motiv ali ga ne bo?

Katja Benevol Gabrijelčič: Same od sebe se ne bodo pojavile, samo od sebe

7 Dostopno na naslovu: http://www.termania.net/?searchIn=Linked\&ld=191. 
se ne zgodi nič.

Nataša Logar: Nadaljujete misel, ki jo je izrekel Urban.

Katja Benevol Gabrijelčič: Absolutno. Vedno mora biti nekdo pobudnik. Kdo, ni tako pomembno - če mu je vseeno, kako sodeluje pri tem, oziroma če ni užaljen, ko se nekaj naredi malo drugače, kot si je zamislil sam. Tudi na seznamu urednikov Islovarja je kup imen, ki že dolgo niso aktivna, ker so izgubili interes. Ko na slovaropisni skupini določeno zbirko proglasimo za urejeno, gre še enkrat do vseh urednikov, ki lahko, če želijo, podajo pripombo na kateregakoli od urejenih izrazov. Dogaja se več stvari, tudi če pustimo neodzivnost ob strani. Če je nekdo vnesel izraz, ki smo ga nato ocenili za ne najboljšega in prilagodili ali spremenili - sploh po posvetu s slavistkami - in še močno predrugačili razlago, ker je bila prej s sedmimi vrsticami praktično neleksikografska in to ni bila več definicija, ker ...

Nataša Logar: Enciklopedična.

Katja Benevol Gabrijelčič: Tako, ja ... Potem je lahko kdo tudi užaljen. Tu ni kaj: ali delaš za skupno dobro ali pa ne. Vedno moraš biti pripravljen, da bo nekdo vedel nekaj več od tebe in se mu bo nekaj zdelo bolje drugače. To sprejemanje zahteva velikega človeka, kako naj rečem [smeh].

Nataša Logar: Kaj bi motiviralo vaju, Urban, Katarina, da bi to počela? Ali pač nekega visokošolskega učitelja, saj ne gre za vaju osebno.

Urban Bren: Najprej že to, da bi se v Cobissu navedlo avtorstvo, da si prispeval k skrbi za slovenski jezik.

Nataša Logar: Pa pri habilitaciji, verjetno?

Urban Bren: Pa pri habilitaciji, ja. Če bi bilo merilo, da se pričakuje od univerzitetnega učitelja, da skrbi za svoj jezik, kar je ... Ampak jaz nisem pristaš palic, sem bolj pristaš korenčkov. Drugo, ob kar vedno trčimo, so pa seveda sredstva. Ljudje so ali pa smo vedno manj pripravljeni delati zastonj. Razna društva, ki se ustanavljajo za zaščito slovenskega jezika - če so resna v svojih 
namenih, bi bilo dobro podvojiti sredstva, namenjena terminologiji. Slovenščina bo, kot sem rekel, preživela ali padla skupaj z novimi izrazi, ne pa $\mathrm{s}$ tem, ali hodimo od trgovine do trgovine in gledamo, ali imajo popolnoma slovenska imena. Skratka, kjer ni denarja ... $\mathrm{Z}$ besedami je vedno enostavno skrbeti za jezik in podpirati razvoj jezika, ampak na koncu je treba z novci stopiti za svoje besede, ali pa ni ničesar.

Sašo Dolenc: Čeprav jaz ne bi zanemaril ljubiteljskega potenciala. Moramo se zavedati, da je Wikipedija, ki je zdaj nekakšna referenca, nastala iz ljubiteljske dejavnosti množice ljudi, ki jih sploh ne poznamo. Mora pa biti postavljen nek okvir, znotraj katerega se deluje in ki ima tudi definirane uredniške stopnje, da se ve, kako se skrbi za kvaliteto. Če bi se postavilo nekaj takšnega, bi se mogoče našlo ... Ne vem, rekli ste, da v vaši skupini sodelujejo v glavnem upokojenci. Mogoče je upokojencev, ki jih zanima tako delo, v Sloveniji še desetkrat ali stokrat več. V končni fazi pa tudi mladih, ki bi se našli in take stvari urejali. Mogoče ni vse na univerzitetnih profesorjih, ki so že tako preobremenjeni.

Katja Benevol Gabrijelčič: Moja empirična izkušnja pravi, da je tega vedno manj. Včasih so se raznovrstni uredniki še prijavljali, danes zelo redko naletiš na to. Pa govorim samo o dvanajstih letih.

Katarina Krapež: Mislim, da smo padli v nek trend, o katerem danes še nismo nič razpravljali, in to je razvrednotenje dela avtorjev v znanosti.

Katja Benevol Gabrijelčič: Absolutno.

Katarina Krapež: Namreč, poslovni model se je popolnoma obrnil. Nekoč so tovrstno dejavnost financirale založbe in uporabniki smo to kupovali. O tem v osnovi govorimo v avtorskem pravu, kjer se nam je vse obrnilo na glavo. Del situacije smo pravzaprav mi vsi. Kaj se danes nagrajuje v znanosti? Le še izvirni znanstveni članek. To moraš imeti. Če delaš na terminoloških projektih, če pišeš recenzije taistih znanstvenih člankov, kar je del procesa, da znanstveni članek ugleda luč dneva, pride v časopis - tudi to ni ocenjeno. Vse tisto, česar danes ne ocenjujemo - to ni problem našega romantičnega občutka za jezik. Gre za to, 
da tovrstno delo več let ni bilo ustrezno vrednoteno in da je na tem področju resnično nujno že včeraj nekaj narediti.

Kaj to pomeni? Čisto konkretno je treba pogledati pri ARRS, kako se točkuje in zakaj se temu delu ne da točk. Kje so glavni razlogi? Ne mislim, da to preprečuje kakšen tretji brat ali stric iz ozadja. Mislim, da se tega enostavno nismo ustrezno lotili. Morda smo preveč kopirali sisteme, ki tudi v tujini ne delujejo. S strokovnimi recenzijami imamo povsem isti problem. Nihče noče recenzirati člankov, uredniki recenzije krvavo potrebujejo in potem žicamo drug drugega, če bi »naredil tisto recenzijo «. Zakaj: v resnici bi zelo radi kakovostno recenzijo. To je povsem isti problem. Ja, upokojenci. In ja, denar. Ampak v osnovi je treba tudi sistemsko urediti, da ima to delo viden učinek na ugled, da šteje pri habilitaciji. Celoten sistem bi moral to podpreti, da ne bo več propadalo. Mogoče postavimo to kot vrednoto. Danes morda gledamo v kapitalističnem duhu, češ: »To mi ne prinese denarja. « Kar pa ni tako nepomembno, ko je treba plačati najemnino, hrano in tako naprej.

Mojca Žagar Karer: Moram reči, da imamo mi tudi mlajše sodelavce in se nam še javljajo. Mislim, da problem ni le generacijski.

Katja Benevol Gabrijelčič: Še je upanje.

Mojca Žagar Karer: Še je upanje. Moram se strinjati, da denar našim sodelavcem nikoli ni bil glavno gonilo. Vedno so prišli ljudje, ki so čutili afiniteto do tega dela. Še vedno prihajajo in tisti delajo. Tisti, ki ne, pa ne delajo, honorar gor ali dol (honorarjev zdaj tako ali tako ni več). Ampak ni se spremenilo: nekateri ljudje delajo, nekateri ne delajo. Mislim, da je okvir, o katerem je govoril Sašo, zelo pomemben. Da se ne dela kar tako, ker ima nekdo ravno čas, ampak da je to projekt, kjer se ve, kam gremo in kaj je cilj. Ali je to slovar ali ureditev nekega področja, karkoli.

Urban Bren: Če gledamo z motivacijskega stališča: če se znajdem pred problemom in bi obstajala neka spletna rešitev, kjer so povezani drugi iz moje stroke in še terminolog, je nagrada seveda že to, da sem dobil odgovor na svoje 
vprašanje. Če se vsi ti odgovori različnih strokovnjakov nekje tudi zbirajo, je to vsesplošno ugoden kolateralni rezultat. Se pa strinjam, da se mora najprej vzpostaviti klima, ki to sploh ceni in vrednoti.

Katja Benevol Gabrijelčič: In osnovna struktura.

Katarina Krapež: Tukaj se mi zdi, da lahko vaša stroka ogromno naredi. Veste, kaj bi ocenjevali in kako, čemu bi dali vrednost. To lahko pride samo od nas. Jaz lahko na pravnem področju povem, kaj prinaša dodano vrednost razen izvirnega znanstvenega članka. Zelo težko bi pa razumela, kaj točno in kako bi vrednotili v terminologiji: če sestavim slovar ali sodelujem pri tem ... Z naborom tovrstnih dejavnosti je treba iti do ARRS in se začeti o tem pogovarjati. Saj je zoprno, ali ni?

Katja Benevol Gabrijelčič: Ne, ne znam si čisto predstavljati, mogoče se mi bo še kaj izkristaliziralo.

Nataša Logar: Nakazali smo, da različne poti so, da je interes. Da je potreba, smo vedeli že prej. Da so tehnične možnosti, ki jih že poznamo in ki jih lahko samo še izboljšamo. Da smo še vedno motivirani, vemo pa tudi, kako bi se nas dalo bolje motivirati. Da ni izbire - treba je iti na splet, biti odprt ... Tu je še množičenje. Treba je dati priložnost ljudem, ki se mogoče ne oglasijo neposredno na inštitutu, bi pa od doma kaj prispevali anonimno. S tem zaključujem prvi del panela in dajem besedo občinstvu. Darja?

Darja Fišer: Živijo, vse bi lepo pozdravila, jaz sem Darja Fišer. Dve stvari bi odprla - bolj odprla kot karkoli zapirala. Prvo, pri dveh govorcih v sredini se mi poraja misel: oba se zanašata na to, da bo terminologijo delal jezikoslovec. Stroka se odmika od odgovornosti za terminologijo in reče: »Jaz nisem jezikoslovec.« Pričakuje, da bo terminologijo delal jezikoslovec. Jaz sem jezikoslovec, ampak pričakujem ravno obratno.

Nataša Logar: Jaz sicer nisem razumela, da sta ...

Darja Fišer: Te nastavke sem zaznala, no. Kje je dodana vrednost, da 
terminologijo delajo jezikoslovci, ne pa stroka? To je ena stvar. Druga stvar pa je, da se mi zdi, da je točkovanje ali tovrstno rigidno sistemsko nagrajevanje terminologije obsojeno na neuspeh.

Urban Bren: Tako, Darja, ne da delam terminologijo, tedensko jo delam. Kljub temu da nisem jezikoslovec. Kar sem si želel, ni, da jezikoslovec to dela. Da to delam jaz, ampak da imam pri tem tudi podporo jezikoslovca, pomoč, če čutim, da jo rabim. Je tudi ne bom rabil pri vsakem terminu, ampak pri kakšnem bi mi pač prišla prav.

Mojca Žagar Karer: Tukaj se res lahko obrnete na nas, prav v takih primerih.

Katarina Krapež: Ker konstruktivna razprava je res ...

Urban Bren: Konstruktivna razprava z nekom drugim, ne s samim sabo v svoji glavi.

Katja Benevol Gabrijelčič: Lahko dopolnim?

Urban Bren: Absolutno.

Katja Benevol Gabrijelčič: Jaz sem bila na obeh bregovih hkrati. Sem jezikoslovec, ampak v slovarsko skupino sem prišla kot nekakšen hibrid računalničarja in jezikoslovca. In $\mathrm{z}$ ogromnim naborom kalkov, ki se je $\mathrm{v}$ računalništvu pojavil, še preden smo mi sploh stopili na sceno. Ker večina strokovnjakov nima izhodišč, na podlagi katerih bi nekomu besedotvorno razložili: »Ta stvar dela to in to, izhaja iz tega in iz tega korena mi stvorite nekaj, kar je v slovenščini besedotvorno vzdržno. « Ampak naredijo kalk in imamo potem del terminov, ki jih norma odriva $\mathrm{v}$ žargon (v Islovarju imajo oznako »pogovorno«). V stroki pa se uporabljajo, čeprav večina ve, da bi moralo biti malo drugače. Tako iz izkušenj.

Mojca Žagar Karer: Jaz se strinjam z Darjo, da je terminologija stvar stroke, ker je ne bo nihče uredil, če je ne bo stroka sama. Kje pa stroko podpreti in kako, je stvar, o kateri se je treba dogovoriti. Možnosti je zelo veliko. V stroki, ki ne čuti potrebe, da se ta sistem uredi, se ne bo zgodilo nič. Tudi če jim bo nekaj 
ponujeno, se ne bo zgodilo nič, ker ni motivacije.

Katarina Krapež: To, o čemer sva govorila midva, je mogoče bolj tista zagata, v kateri se človek znajde. Čuti veliko odgovornost in potrebuje pomoč, ker se zaveda, da ni ustrezno strokovno podkovan. Kar je omenila Katja, je odličen prikaz tega, kar se dogaja. Morda nimaš ustrezne besede, je ne najdeš, ker se s tem ne ukvarjaš vsak dan. Terminologi ste v tem bistveno boljši. Jaz bom seveda znala zelo hitro presoditi, ali sodi v okvir, ali je ustrezno. Rabim pa nekoga - če tvorim sama - ki mi sugerira: »To bi šlo. Tu pa morda razmisli še tole in tole.« Saj je podobno na pravnem področju. Ko nekdo rešuje vaš problem, vam bo rekel: »Varianta A, B ali C?« Vi boste rekli: »B nikakor, C bo pa šlo.« Na ta način. Mislim pa, da ne eden ne drugi nimava občutka neodgovornosti - da bi to morali početi jezikoslovci. Daleč od tega, saj se zavedamo, ampak ja ... Včasih bi ga bilo fino imeti takole $\mathrm{v}$ žepu zraven [smeh].

Darja Fišer: Nisem mislila odgovornosti, kdo dela, ampak kdo je kompetenten to početi. Tu sem zaznala ...

Katarina Krapež: Ja, ja, razumem. A sem se malo popravila [smeh]?

Katja Benevol Gabrijelčič: Po mojih izkušnjah tisti strokovnjaki, ki težijo k temu, da bi se njihovo področje tudi jezikovno uredilo, iščejo in so pripravljeni razumeti stvari, ki jim jih razloži jezikoslovec. Če vzamemo za primer povsem butasto besedo, na katero sem alergična - implementacija. Tej besedi je računalništvo dodalo pomene, ki daleč presegajo angleško razlago besede implementation. Zato jim ni dovolj ne uvajanje, ne izvedba, ne nič, ker nobene od teh besed $\mathrm{v}$ maternem jeziku ne razumejo tako, kot razumejo implementacija. Tu je sociološka komponenta ali navezanost na domačo besedo, ki se stepe s tistim, kar razumeš pod neko strokovno besedo. Čeprav jim jezikoslovec razloži, da lahko tudi besedi uvajanje (sistema, česarkoli) podeliš enake pomene, kot jih čutijo pri besedi implementacija, potem besede uvajanje ne bodo uporabljali, ker jim ne zadošča.

Nataša Logar: Še kakšna misel? Vojko? 
Vojko Gorjanc: Na začetku ste pravzaprav odprli diskusijo o tem, da smo v prehodnem obdobju, in zdi se mi, da se tudi na drugih področjih dogaja podobno. Navajeni smo bili na nek drug model, zdaj prihaja nov model, kjer se gradijo tudi druge, nove skupnosti. Te skupnosti se gradijo z drugačnimi pričakovanji, tudi glede dostopa do virov (v katerem mediju, prostega dostopa) in so za take stvari velikokrat pripravljene tudi same prispevati. Ampak morajo se samoorganizirati in to prepoznavati kot vrednoto, kamor vlagajo. Ravno prejšnji teden sem bil na konferenci, ${ }^{8}$ kjer se je izkazalo, da nečesa, kar je bil krasen model - jaz bi rekel »model katedrale « 9 - preprosto ne razumejo več kot zgled dobrega modela. $\mathrm{V}$ model, ki je veliko manj lep, ampak robusten in vanj vsi prispevajo, $\mathrm{v}$ tistega pa so pripravljeni vlagati. $\mathrm{V}$ tem ni nobenega problema.

Zdi se mi, da je institucionalna podpora na način, kot ga ponuja ARRS, ubijanje poskusa novega modela dela že v samem začetku, ker samo perpetuira nekaj že obstoječega. Imamo izvirni znanstveni članek, rabimo recenzente. Delamo recenzije zato, da bomo imeli izvirni znanstveni članek. Zdaj bomo pa še vrednoteni za to. Jaz z velikim veseljem gradim skupnost in pišem recenzije, kjer se mi zdijo smiselne: kjer bo na koncu boljši članek, kjer delamo vsi skupaj kot skupnost. To mi ni noben problem, to je del mojega univerzitetnega dela. Kjer pa pričakujejo od mene, da bom napisal recenzijo, da bo to izvirni znanstveni članek, pa hvala lepa. Tudi če mi boste dali točke za ARRS. To je ubijanje smisla tega, kar počnemo kot skupnost.

Nataša Logar: To ste rekli prej, Katarina, da vrednotenje ...

Katarina Krapež: Pravzaprav imava podobno izhodišče: sistem, kakršen je, ne deluje. Delala sem raziskavo med 258 uredniki znanstvenih revij, ${ }^{10}$ kako bi izboljšali komunikacijo v znanosti glede najzanimivejših rezultatov - projektov,

\footnotetext{
8 Povezava na predstavitev konference: http://www.orcit.eu/conference16/.

9 Urejen, hiarhično voden model delovanja, s par strokovjaki, ki vodijo in nadzirajo delo, in množico delavcev (Gorjanc 2011).

${ }^{10}$ Raziskava je opisana v Krapež (2016).
} 
raziskav in tako dalje. Med temami so bile tudi strokovne recenzije, zlasti to, da jih delamo zato, da jih delamo. $\mathrm{V}$ teh recenzijah ničesar več ne prispevamo. Avtor ne dobi povratne informacije, ki bi jo pričakoval. Ni konstruktivne debate, izmenjave mnenj, ki bi jo potreboval, da bi bil članek boljši. Na koncu smo ugotovili, da je recenzentsko delo vsem malo odveč, ker imajo »drugo, pomembnejše delo«. Nato smo pogledali, kaj to je. Ugotovili smo, da je "pomembnejše delo« tisto, ki je ovrednoteno, in tisto, za kar so ti ljudje pravzaprav plačani. Potem spet pridemo do osnovnega vprašanja. Seveda: sistem ne bo ničesar rešil, same točke ne bodo ničesar rešile. Ampak uspešni avtorji so pisali znanstvene članke, predavali in zelo malo recenzirali -izogibali so se tega dela.

Mladi avtorji, ki bi radi prišli v sistem, niso bili podprti. Sistem jih ni podpiral v smislu, da bi jim dal konstruktivne predloge, kako vsebino zboljšati - ker tisti, ki naj bi bili mentorji, ne morejo biti mentorji, ker delajo nekaj drugega, za kar dobivajo točke, honorarje in podobno. Pridemo pa tudi do drugega sklepa: da v znanosti ne delamo izključno za denar. Zelo veliko je na ugledu, razvoju, napredovanju. Ni tako črno-belo, da same točke ne prinesejo napredka, ampak gre za celo sistemsko podporo, kako narediti znanost kakovostnejšo. Vse, kar pravim, je, da tudi terminologija bistveno prispeva k temu - in vsi ljudje, ki se s tem resno ukvarjajo. In da zdajšnji sistem tega sploh ni prepoznaval. To je zaskrbljujoče, ker se dogaja že leta. To boste vi bolje vedeli kot jaz.

Vojko Gorjanc: Ampak gre za raziskavo znotraj Slovenije.

Katarina Krapež: Ne, to je bil svet. Vsi kontinenti. Zato pravim, da to sploh ni tako slovenski problem. Priznam, da je tudi mene presenetilo. No, ampak okrogla miza ni o moji raziskavi. Vidim pa podobnost teh dveh tem.

Urban Bren: Avtorje nas režejo kot salame. Na eni strani avtorstvo slovarja ne prinese ničesar - Miro, vi bi najraje videli, da človek, ki je zadevo zbral, prinese še 3000 EUR, da mu tehnično pomagate ...

Nataša Logar: Drugače na Amebisu za to delo niso plačani. 
Urban Bren: Razumem, če bi hoteli imeti ure pokrite, bi rabili še to. Potem, napišemo izvirni znanstveni članek, ga pošljemo v revijo, jim damo vse svoje avtorske pravice, da oni potem to prodajajo. Če dajo odprti dostop, jim pa še plačamo, da naše avtorsko delo objavijo. Mislim, avtorsko delo je popolnoma strmoglavilo in se razvrednotilo.

Nataša Logar: Če pohitimo naprej, Simon in ... Špela?

Špela Arhar Holdt: A lahko kar jaz začnem, Simon bo sigurno zaključil debato [smeh].

Nataša Logar: Lahko dodam, Simon, da panelistom nisem dala brati tvojega članka. ${ }^{11}$

Simon Krek: Saj ne bom o tem.

Špela Arhar Holdt: Hotela sem samo izpostaviti, da vsekakor govorimo o različnih vrstah problemov in o različnih vrstah rešitev. Verjetno je smiselno od širših skupnosti pričakovati in jim tudi ponuditi možnost, da prečiščujejo podatke, da sopostavljajo terminologijo s prevodom, ne moremo pa najbrž pričakovati od množic, da bodo pisale definicije ali podobno. Ampak do neke meje sigurno lahko pridemo, mogoče tudi z močjo študentov, če že profesorji nimajo časa tega delati; ta sila se najbrž lahko na nek organiziran način vključi v sodelovanje. Od določene točke naprej je pa treba, se strinjam, razmisliti o tem, kako bo visokokvalificirana sila - ki jo imamo v procesu zato, da to počne - ustrezno nagrajena. Konec koncev je sistem tak. Mislim, da so vse te rešitve prave.

Miro Romih: Samo toliko, prej ste omenili Cobiss, ne? Kot zanimivost povem, da smo imeli od tistih nekaj deset slovarjev, ki so sedaj na Termanii, za sedem slovarjev na začetku vprašanja, če bodo vidni v Cobissu. To je bilo tisto: »Aha, če bo, potem pa dam svoj slovar, ker je to zame zanimivo.«

\footnotetext{
${ }^{11}$ Gre za prispevek S. Krek (2014).
} 
Katja Benevol Gabrijelčič: Vsaj nekaj, ne.

Miro Romih: In smo že od začetka ... Velika večina slovarjev v Termanii ima vpis, imamo navezo z NUK-om, ${ }^{12}$ kot Termania smo založnik.

Mojca Žagar Karer: Zbirka Termania, ne?

Miro Romih: Vedno organiziramo še vpis v Cobiss, da avtor dobi vsaj nekaj. Če ne bi imeli tega, bi bili brez sedmih slovarjev, ki jih sicer imamo. Tudi to lahko komu nekaj pomeni. Lahko bi obstajalo še kaj tovrstnega.

Katja Benevol Gabrijelčič: Ja, saj. Gratifikacij je dosti oblik, daleč od tega, da bi štartali iz finančne. Vsi smo štartali brez finančne. Ampak sčasoma se zgodi, da ti v glavi zadeva razvodeni, ker ni nikakor priznana. In tudi sicer nimaš dovolj ... Mislim, če bi bile druge stvari dovolj plačane, potem bi tudi to brez težav delal zastonj. Kako naj rečem? Točno vidim, kako je z upadom prevajalskih tarif $\mathrm{v}$ zadnjih desetih letih razvodenelo zanimanje, da bi prevajalci brezplačno sodelovali pri slovarju. To je moja izkušnja.

Urban Bren: Žal s prostovoljnim delom navajamo skupnost, da to itak ni vredno, to bodo pa ja zastonj delali.

Sašo Dolenc: Ne.

Katja Benevol Gabrijelčič: Tudi hkrati, ja.

Miro Romih: Pa še nekaj v zvezi s plačljivostjo dela. Mogoče je razlika tudi med nami, ki smo ponudnik storitve kot tehnični servis, ali pa nekom, ki dela slovar. Vsak ima kot avtor samo svoj slovar (recimo) in lahko pričakuješ, da mogoče za tisti slovar dela zastonj. Težko pa Amebis postane vsenacionalni servis, ki bo nosil vse stroške za vse slovarje. Čeprav za vaš slovar mogoče samo tri ure, za drugega tri ure ... Ampak, kot sem rekel: krat toliko in toliko slovarjev. Ne moremo biti mi nosilec - mislim, z veseljem bi bili tehnični nosilec, če bi bili vsaj pokriti za svoje delo. To ni noben problem.

${ }^{12}$ Narodna in iniverzitetna knjižnica (http://www.nuk.uni-lj.si/). 
Kot pravim, platforma je brezplačna, razvili smo jo brezplačno, še vedno skrbimo zanjo in imamo tudi namen, dokler bo šlo. Vzpostaviti pa je treba nek servis ali pa recimo ... Ker imamo dva problema. Imamo obstoječe slovarje, ki zahtevajo konverzijo, s čimer je ponavadi največ dela. (Če dobimo zelo urejen slovar, je dela zelo malo.) Potem so pa tu še novi slovarji, ki jih pravzaprav še ni. $\mathrm{Tu}$ imamo pa povezavo s korpusi, nekimi postopki, uvozi, novimi tehnologijami, kjer so pa mogoče tudi drugi udeleženi. Recimo, KAS kot izvor besedil, Špelin ekstraktor. ${ }^{13}$ Potem lahko uvozimo v urejevalnik oz. okolje za urejanje. Torej je več dejavnikov, ampak ta servis, se mi zdi, bi moral biti plačljiv. Kot sam razvoj platforme, funkcionalnosti, ali pa strežnik kot tak, ki bi mogoče moral biti na Arnesu ali kaj podobnega, da nek nosilec skrbi za ta del.

Mojca Žagar Karer: Glede motivacije se pravzaprav strinjam. Mi večinoma delamo z univerzitetnimi profesorji in velikokrat rečejo, da bi jih motiviralo, če bi bile točke ARRS. Iz prakse lahko potrdim, da to motivira ljudi - bi jih. Motivira jih recimo tudi to, če se cel oddelek fakultete odloči, da bo sodeloval pri določenem terminološkem projektu. Potem skušajo motivirati drug drugega, ker pač nočejo ostati tisti, ki niso prispevali za svoje podpodročje. To tudi pomaga. Tudi terminološki dogovor je lažji znotraj strokovne skupnosti. Saj se vedno pojavi nekdo, ki se ne strinja in skuša uveljaviti svojo rešitev. Ampak če je ljudi dovolj, če so motivirani, to presežejo in se dogovorijo. Skratka, motivacija je, da sodelujejo skupine, ki so tudi formalno povezane.

Nataša Logar: Simon?

Simon Krek: Moram poudariti, da samo nadaljujem to, kar je povedal Vojko. Mislim, veliko imam za povedati, ampak ... Zdi se mi, da ni bilo čisto dobro razumljeno, kako zares pomembno je zamenjati konceptualni model obvladovanja terminologije. Koncept. Da si lažje predstavljate, je še najlažje dati primer Wikipedija proti Enciklopedija Britannica, kjer se je v resnici cel znanstveni svet zelo dolgo upiral menjavi modela: da je sploh možno z

13 Ekstraktor terminoloških kandidatov Luiz (Vintar 2010). 
množičenjem priti do nečesa, kar je tako kvalitetno, tako kulturno, tako kultivirano - in hkrati ekstremno uporabno. Tako sem jaz Vojka razumel. Sedajle, ko ste govorili, ste bili v marsikaterem stavku nosilci starega modela razmišljanja o obvladovanju terminologije. Lahko vam povem par primerov. En je ta, da sploh ločujemo med strokovnjaki in uporabniki. To je tako, kot da bi nase dal kapo strokovnjaka in naredil članek v Wikipediji, naslednji trenutek pa bi bil uporabnik, ki je »samo« prevajalec ali »samo« lektor ali ne vem kaj. Obstaja samo uporabnik terminologije, nič drugega.

Druga stvar je ta, da obstaja nekaj fiksnih idej o jeziku, ki ovirajo razumevanje tega, kar je (po mojem razumevanju) povedal Vojko. Recimo - da je nekoč obstajalo neko kmečko prebivalstvo, ki ni imelo terminologije. Seveda so imeli terminologijo, na to je bil samo naložen koncept neke standardizacije jezika, ampak za tiste specifične stvari, ki so jih uporabljali, so pač imeli terminologijo. In to je ista terminologija - konceptualno jo je treba razumeti na isti način kot se sedaj pogovarjamo o tem, da nekdo naredi svojo malo Wikipedijico iz določenega terminološkega področja. Kot rečeno, to se mi zdi najpomembnejše sporočilo sploh. Treba je zamenjati, konceptualno, način obvladovanja terminologije. Tehnika je na voljo, absolutno. Miro je omenjal, marsikdo je omenjal. Če pride financiranje, seveda toliko bolje. Ampak če se zamenja v glavi model obvladovanja terminologije, je absolutno rešljivo marsikaj, kar se zdajle zdi nerešljivo.

Nataša Logar: No, saj smo bili kar optimistični ... [smeh] Mateja?

Mateja Jemec Tomazin: Zdravo, Mateja Jemec, za tiste, ki me ne poznate. Navezala bi se na zadnje tri in mogoče poudarila, da se moramo pri novem konceptu in novem razmišljanju o terminologiji dogovoriti za soglasje. Wikipedija v angleščini zaradi precej večjega števila uporabnikov doseže, kar je dobro - lahko dosežejo skupni konsenz, da je uporabno. V Sloveniji pa je vseeno treba pripoznati, da imamo težave že s tem, da konsenz dosežejo strokovnjaki iz Ljubljane, Maribora in Kopra. Pri delu na Inštitutu se nam pokaže, da to ni 
tako zelo samoumevno.

Korpus akademske slovenščine bo ponudil odlično osnovo. Vendar kdo bo, kakšen bo način, kako se bomo dogovorili za način, kako to prefiltrirati in kaj od tistega bo ostalo, da bodo posamezne strokovne skupnosti prepoznale, da je to terminologija, ki jo lahko uporabijo oz. da jo lahko kot ustrezno uporabijo prevajalci. Tukaj je to znanje, od besedotvorja - pa to ni najbolj usoden problem, ampak nekateri ga čutijo kot problem. Drugi pa čutijo, da s kalki ni nič narobe in dobro živijo s tem in zaradi tega se tudi ta del terminotvorja ne razvija. Ampak v resnici moramo najti skupen način, kako iz tistega, kar imamo, s tistim, kar lahko naredimo, najdemo različne načine ugotavljanja zanesljivosti, da bodo s tem zadovoljni najširši krogi. Ali je terminologija - če zbanaliziramo - ko reče otrok pri zdravniku: »Boli me trebušček « in mora zdravnik vedeti, kaj je lahko tisti trebušček. Trebušček je za otroka uporabljen terminološko. Tega v resnici ne moremo prepustiti komurkoli oz. lahko, če imamo zraven predpostavljen nadzor.

Simon Krek: Naj povem samo en stavek. Kar si sedajle povedala, Mateja, govori samo eno: da to, kar sva govorila z Vojkom, absolutno ni bilo razumljeno. Skupnost je treba organizirati na način, da se to dogaja samo od sebe. Tako je Wikipedija tudi nastala, ker sama sebe - z nekimi uredniškimi posegi - gradi v zelo dober vir. To je koncept, o katerem govorimo. Kar si rekla ti, ni ta koncept.

Mateja Jemec Tomazin: Ampak uredniški koncept ostaja.

Simon Krek: Uredniški koncept, ki je organiziran na tak način, da se vir gradi sam od sebe. Ne pa s posegi določene usmeritve, da tako rečem.

Mojca Žagar Karer: Kakšna je pa potem uporabnost tega vira? Kaj dobimo? Še ne vemo?

Simon Krek: Vemo, da dobimo končne rezultate, ki so vedno bolj izčiščeni iz same skupnosti.

Nataša Logar: Mislim, da bomo to preizkusili in se lahko potem o tem 
pomenili.

Miro Romih: Jaz imam še eno vprašanje za vas, ki se ukvarjate z vsebino. Kot sem že omenil, po eni strani vidim, da imajo ljudje veliko slovarjev, ki jih ne znajo spraviti do drugih. Kakršnikoli ti slovarji že so, nekaj znanja in koristnih informacij tam je. Na drugi strani je težnja, da bi se vsi slovarji delali po novih metodah, kot pravi Simon. Ampak preden se vse to zgradi, bo trajalo deset, dvajset let, ne vem - ali pa par let. Ali je torej sploh smiselno jemati nekaj starega ali je bolje poradirati in iti na novo?

Simon Krek: A to je vprašanje zame?

Miro Romih: Ja, recimo. Kaj mislite, kakšna je vrednost starih slovarjev iz predalov ali nekih skovanih slovarčkov? Ali to uporabiti, ali sploh vlagati napor, da se naloži v nek skupen repozitorij (ob slovarjih, ki so že narejeni, kjer ima vsak svojo strukturo)? Ali združiti nov sistem, pa kljub temu še stare zraven? Eni zagovarjajo stare, eni samo nove, eni pa oboje.

Simon Krek: Odgovor je v bistvu zelo preprost: vsaka informacije je dobra informacija.

Miro Romih: Se pravi: če je enostavno priti do nekih materialov, zakaj ne.

Nataša Logar: Se podpre, ja.

Miro Romih: Ker to je vezano na odkup nekaterih slovarjev, za katere vemo, da obstajajo, pa niso več dostopni ljudem na pravi način. Primer so dvojezični, pa tudi terminološki, seveda.

(Nekdo iz občinstva): A so aktualni? Kdo potem to presoja oz. kdo je dal to oceno? Predstavljam si, da strokovnjaki, ne?

Miro Romih: Ja, recimo, bom povedal primer. Večinoma so to društva, fakultete in podobno. Npr. Inženirsko seizmološki terminološki slovar ali pa Statistični terminološki slovar, ki ga je dalo Statistično društvo Slovenije. Na pogled je kar nekaj informacij. Ampak je bilo precej dela, da smo ga spravili v 
obliko, da lahko sploh uporabljamo iskanje po njem. Hočem reči, da je bil nek napor potreben, in nekateri so to financirali, drugi pa pač ne. V prvem primeru slovar je, v drugem pa vemo, da obstaja, ampak samo v njihovem predalu.

Nataša Logar: Hvala [obrnjeno proti občinstvu]. Ter hvala lepa govorcem in govorkam. Nadaljujemo ob drugi priložnosti! [Aplavz publike.]

\section{ZAHVALA}

Izvedbo in zapis panela je podprl projekt ARRS J6-7094 »Slovenska znanstvena besedila: viri in opis«.

\section{LITERATURA}

Akcijski načrt za jezikovno opremljenost (2015). Ljubljana: Ministrstvo za kulturo RS. Dostopno prek:

http://www.mk.gov.si/fileadmin/mk.gov.si/pageuploads/Ministrstvo/raziskaveanalize/slovenski_jezik/Akcijska_nacrta/ANJO.pdf (30. september 2016).

Erjavec, T., Fišer, D., Ljubešić, N., Logar, N. in Ojsteršek, M. (2016): Slovenska akademska besedila: prototipni korpus in načrt analiz. V T. Erjavec in D. Fišer (ur.): Zbornik konference Jezikovne tehnologije in digitalna humanistika: 58-64. Ljubljana: Znanstvena založba Filozofske fakultete. Dostopno prek: http://www.sdjt.si/wp/wpcontent/uploads/2016/09/JTDH-2016_Erjavec-et-al_Slovenska-akademskabesedila.pdf (30. september 2016).

Gorjanc, V. (2011): Language resources and corpus-driven community interpreter training. V: C. Kainz, E. Prunč in R. Schögler (ur.): Modelling the field of community interpreting: questions of methodology in research and training, str. 284 (Repräsentation Transformation, Bd. 6): 280-297. Wien: Lit.

Krapež, K. (2016): Avtorskopravni standard originalnosti in regulacija originalnosti v znanosti: primer znanstvenih revij [doktorska 
disertacija]. Univerza na Primorskem, Fakulteta za management. Dostopno prek: http://www.ediplome.fm-kp.si/Krapez_Katarina_20160719.pdf (30. september 2016).

Krek, S. (2014): Terminologija kot storitev. Teorija in praksa, 51 (4): 670683. Dostopno prek: http://dk.fdv.uni-lj.si/db/pdfs/TiP2014_4_Krek.pdf (30. september 2016).

Vintar, Š. (2010): Luščenje terminologije iz angleško-slovenskih vzporednih in primerljivih korpusov. V: Š. Vintar (ur.): Slovenske korpusne razsikave: 37-53. Ljubljana: Znanstvena založba Filozofske fakultete.

To delo je ponujeno pod licenco Creative Commons: Priznanje avtorstvaDeljenje pod enakimi pogoji 4.o Mednarodna.

This work is licensed under the Creative Commons Attribution-ShareAlike 4.0 International.

https://creativecommons.org/licenses/by-sa/4.o/

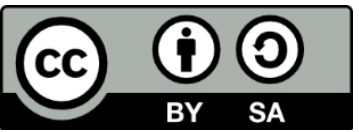

